\title{
Herne lakoutuu harvoin, tukikaura varmistaa loput
}

\author{
Hannu Känkänen, Heikki Jalli, Lauri Jauhiainen
}

MTT Kasvintuotannon tutkimus, 31600 Jokioinen, etunimi.sukunimi@mtt.fi

\section{Tiivistelmä}

Herneen viljelyvarmuus on kehittynyt viimeisen puolen vuosisadan aikana kenties enemmän kuin minkään muun peltokasvilajimme. Aikoinaan peltoherne kasvoi metrikaupalla maata pitkin ja kukki pitkälle syksyyn. Sitten löydettiin mutantti hernemuoto, jossa lehdykät olivat muuttuneet kärhiksi. Jalostus alkoi kohdistua lehdyköiden osittaiseen korvaamiseen kärhillä ja korvakkeiden koon säätelyyn. Myös varren tyven vahvistaminen on ollut tärkeä jalostuskohde.

Ensimmäinen suomalainen puolilehdetön lajike, Hankkijan Tammi, laskettiin kauppaan 1984. Vasta sen jälkeen tulleiden lajikkeiden myötä laonkesto parani. Nykyiset puolilehdettömät hernelajikkeet pysyvät pääsääntöisesti pystyssä. Liian multavassa maassa tai kasvun kannalta erityisen edullisissa kosteusoloissa herne kuitenkin voi lakoutua etenkin, jos palon täyttymisen aikaan tulee runsaita sateita. Silloin tukikasvi voi auttaa herneen pystyssä pysymistä.

Peltolohkovalinnan, tukikasvin käytön ja rikkakasvien torjunnan lisäksi pystyssä pysymistä voi varmentaa huolellisen kylvön ja riittävän siemenmäärän avulla. Riittävässä tiheydessä herneet pitivät toisiaan kärhien avulla paremmin pystyssä.

Jokioisissa verrattiin eri kevätviljoja herneen tukikasveina kolmena kesänä. Tukiviljoiksi valittiin lajikkeita, joiden laonkesto on hyvä ja kasvuaika mahdollisimman lähellä Hulda -herneen kasvuaikaa. Tukiviljojen kylvötiheys määräytyi sen perusteella, että aiemmissa tutkimuksissa sopivaksi tukikauran osuudeksi siemenseoksen kokonaispainosta oli todettu 7,5 prosenttia.

Herne ei mennyt lainkaan lakoon vuonna 2009 rehevästä kasvustaan huolimatta, eikä myöskään seuraavana, hieman heikompikasvuisena kesänä. Vuonna 2011 lakoutuminen pyrittiin varmistamaan sijoittamalla koe alueelle, joka viljelykokemusten mukaan kasvoi yleensä rehevästi eikä kärsinyt helposti kuivuudesta. Multavuudeltaan tämä hiuesaveksi määritelty maa tosin oli vastaavanlaista kuin ensimmäisen kesän koealue eli luokassa "multava", humuspitoisuuden ollessa hieman yli $5 \%$.

Hyvän kasvun ja lakoutumisen varmistamiseksi varauduttiin sadetukseenkin. Sateet kesän mittaan kuitenkin auttoivat rehevään kasvuun. Runsaat sateet palkojen täyttymisen aikaan varmistivat lopputuloksen: herne meni kolmen vuoden odotuksen jälkeen lakoon. Kaura tukikasvina esti herneen lakoutumista varsin hyvin. Tavallista korkeammaksi kasvanut herne vei tehon kääpiökauralta; se esti herneen lakoa vain, kun herne ei ollut aivan pisimmillään. Ohra piti hernettä pystyssä pidempään kuin kääpiökaura, vaikka lopulta lako niiden kesken oli samaa luokkaa. Kevätvehnä auttoi hyvin heikosti pystyssä pysymistä.

MTT:n pitkäaikaisten herneaineistojen tarkastelu sääaineistojen rinnalla vahvisti oletuksia herneen lakoa aiheuttavista riskitekijöistä. Huomattava lakoriskin lisääntyminen savia kevyemmissä maissa kuvannee osittain lakoherkkyyttä herneen kannalta liian multavissa maissa. Sateet alkukesällä auttavat herneen hyvään kasvuun ja antavat edellytykset runsaaseen palkojen muodostukseen, mikä osaltaan lisää myös lakoutumisen edellytyksiä. Palkojen täyttymisvaiheen sateisuuden lakoa lisäävä riski sai tilastollista vahvistusta. Kesän 2011 tukikasvikoe osoitti, että erittäin lakoalttiissa oloissa kaura on viljoistamme paras herneen lakoutumisen estäjä.

\section{Asiasanat}

Herne, valkuaiskasvit, palkokasvit, kaura, kääpiökaura, ohra, kevätvehnä, kasvinsuojelu, tukikasvi, sekaviljely 


\section{Johdanto}

Herneen viljelyvarmuus on kehittynyt viimeisen puolen vuosisadan aikana suurin harppauksin, kenties enemmän kuin minkään muun peltokasvilajimme. Päätteettömän kasvutapansa vuoksi peltoherne kasvoi ennen metrikaupalla maata pitkin ja kukki pitkälle syksyyn. 1950-luvulla löydettiin mutantti hernemuoto, jossa lehdykät olivat muuttuneet kärhiksi. Jalostus alkoi kohdistua lehdyköiden osittaiseen korvaamiseen kärhillä ja korvakkeiden koon säätelyyn. Myös varren tyven vahvistaminen on ollut tärkeä jalostuskohde. Nykylajikkeet myös valmistuvat aikaisin. Ehkä herne onkin kehittynyt nopeammin kuin asenteet, sillä moni viljelijä pitää hernettä hankalampana viljeltävänä kuin se onkaan. Lakoutumisongelmaa ei silti pidä vähätellä, sillä pahasti lakoutuessaan herne on vaikea puitava, ja kustannukset niin korjuussa kuin kuivauksessakin kasvavat. Suurin este herneen viljelyn lisääntymiselle on sittenkin siitä maksettava alhainen hinta, ja etenkin kylvösiemenen korkea hinta suhteessa sadosta saatavaan korvaukseen.

Viljelyvarmuuden parantaminen johti jalostuksessa ensin täysin lehdettömiin lajikkeisiin. Kärhet kylläkin pitivät kasvustoa pystyssä, mutta lehtialan pieneneminen pienensi myös satopotentiaalia. Tavoitteeksi otettiin herne, jossa oli yhteyttävää lehtialaa mutta myös runsaasti kasvustoa pystyssä pitäviä kärhiä. Ensimmäinen suomalainen puolilehdetön lajike, Hankkijan Tammi, laskettiin kauppaan 1984. Se oli vielä tyvestään heikko, ja vasta myöhemmin tulleiden lajikkeiden myötä laonkesto parani. Nykyiset puolilehdettömät hernelajikkeet pysyvät pääsääntöisesti pystyssä (Känkänen 2011). Liian multavassa maassa tai kasvun kannalta erityisen edullisissa kosteusoloissa herne kuitenkin voi lakoutua. Riskin lakoutumiseen voi olettaa kasvavan herneen kehityksen siinä vaiheessa, kun paino kasvuston yläosissa kasvaa voimakkaasti palkojen täyttyessä. Yhtä oletettavaa on, että runsaat sateet tuohon aikaan lisäävät huomattavasti laon mahdollisuutta. Asiaa ei ole kuitenkaan suoranaisesti todennettu vertaamalla olemassa olevaa tutkimusaineistoa ja sääaineistoja.

Tukikasvi voi auttaa herneen pystyssä pysymistä. Kontturi ym. (2005) totesivat vahvakortisen kauran vähentävän samassa seoksessa kasvaessaan herneen lakoutumista. He myös havaitsivat kauran kilpailevan hernettä voimakkaammin valosta ja arvelivat kokeissa käytetyn 7,5 \% kauraosuuden siemenseoksen painosta olevan vielä liian suuri, kun tavoitteena on nimenomaan hernesadon tuottaminen. Monipalko -hankkeen tukikasvikokeissa haluttiin toisaalta selvittää muidenkin kasvilajien käytön mahdollisuutta tukikasveina ja toisaalta tukikauran kylvön viivästyttämisen merkitystä. Siksi tukikasvin kylvötiheyden perusteena päädyttiin pitämään samaa 7,5 \% tukikauran paino-osuutta siemenseoksessa kuin oli käytetty pienimpänä määränä aikaisemmissa Kovaherne -hankkeen kokeissa.

Peltolohkovalinnan, tukikasvin käytön ja rikkakasvien torjunnan lisäksi herneen pystyssä pysymistä voi varmentaa huolellisen kylvön ja riittävän siemenmäärän avulla. 1980-luvun kokeissa puolilehdettömille ja lehdettömille herneille sopi tiheämpi kylvö kuin lehdellisille lajikkeille (Känkänen ja Kontturi 1988). Puolilehdetön Pika tuotti suurimman sadon, kun kylvötiheys oli 160 kpl m². Kasviyksilöitä oli silloin 120 - 130 neliömetrillä. Riittävässä tiheydessä herneet pitivät toisiaan kärhien avulla paremmin pystyssä. Kylvötiheyden lisääminen lyhensi kasvuaikaa ja pienensi puintikosteutta. Typpipitoisuus nousi hieman ja muutenkin herneiden laatu parani. Siemenkustannus houkuttaa pienentämään kylvötiheyttä. Nykyään neuvotaan pyrkimään 110 - 120 taimen tiheyteen, mutta käytännössä kylvetään vain 120 itävää siementä neliömetrille, jolla määrällä on vaikeaa päästä tavoiteltuun kasvutiheyteen. Taloudellisessa mielessä kyseinen siemenmäärä lienee perusteltu, mutta biologisin perustein ei siementä enää kannata missään tapauksessa tuosta vähentää. Herneen kylvömäärää ei pidä vähentää myöskään tukikasvin käytön yhteydessä. Koska tutkimuksessa pyrittiin nykykäytäntöä vastaavaan herneen kasvutiheyteen, käytettiin myös nyt esiteltävissä tukikasvikokeissa edellä mainittua kylvötiheyttä.

2000-luvun hernekokeissa herne on mennyt lakoon melko harvoin. Tukikasvikokeiden kuluessa, kahden ensimmäisen kesän aikana lakoa turhaan odotellessa, heräsi kysymys lakoutumisen yleisyydestä ja sadeoloista, joissa lakoutumista yleensä tapahtuu. Tätä posteriesitystä ja artikkelia varten verrattiin 1970 -luvulta asti kertyneen MTT:n herneaineiston lakotietoja sääaineistoihin. Lakoutumisen ja sateen ajoittumisen tilastollista riippuvuutta tarkastellaan tässä alustavasti. Tukikas vikokeiden tulosten osalta keskitytään nimenomaan lakovaikutuksiin. Tukikasvin ja sen kylvöajan merkitystä herneen ja tukikasvin väliseen kilpailuun sekä siemen- ja jyväsatoihin tarkastellaan myöhemmissä julkaisuissa. 


\section{Aineisto ja menetelmät}

\section{Tukikasvikokeet}

Monipalko -hankkeen Jokioisten kenttäkokeissa verrattiin eri kevätviljoja herneen tukikasveina (koe 1) sekä tukikauran eri kylvöaikoja (koe 2) vuosina 2009 - 2011. Tukiviljoiksi valittiin lajikkeita, joiden laonkesto on hyvä ja kasvuaika mahdollisimman lähellä Hulda -herneen kasvuaikaa. Tukiviljat ja niiden lajikkeet olivat Kaura (Peppi), kääpiökaura (Kontant), ohra (Tocada) ja kevätvehnä (Anniina). Koe 2 toteutettiin vuosina 2009 ja 2010. Myös sen kauralajikkeena oli Peppi.

Tukikauran osuus siemenseoksen kokonaispainosta vastasi 7,5 prosenttia, joka aiemmissa tutkimuksissa oli todettu tutkituista tukikauran kylvömääristä sopivimmaksi. Painoprosentti muunnettiin itävien siementen määräksi neliömetriä kohti, joten jokaista tukiviljaa kylvettiin 67 kpl itävää siementä neliömetrille. Tukikasvia kylvettiin siten hieman yli yksi siemen kahta herneen siementä kohti.

Kokeessa 1 tukivilja kylvettiin välittömästi herneen kylvön jälkeen, ristiin herneeseen nähden ja normaaliin viljan kylvösyvyyteen. Kokeen 2 tukikauran kylvöajat olivat: 1) samana päivänä herneen kanssa, 2) juuri ennen herneen taimettumista ja 3) herneen ollessa $5-8 \mathrm{~cm}$ pitkää. Molemmissa kokeissa yksi koejäsen kasvoi ilman tukikasvia, toistoja oli neljä.

Kesällä 2009 tukikasvikokeet kylvettiin multavalle hietasavipellolle, jonka pH oli 6,7 ja toisena vuonna hiesusavipellolle, jonka $\mathrm{pH}$ oli 6,1. Vuoden 2011 tukikasvikokeen maa oli multavaa hiuesavea, pH 6,0. Vuoden 2011 koealue valittiin varta vasten sellaisesta paikasta, joka kokemuksen mukaan kasvaa rehevästi eikä kärsi helposti kuivuudesta. Myös sadetukseen varauduttiin, jotta edellytykset rehevälle kasvulle ja herneen lakoon menemiselle olisivat olemassa. Kaikissa kylvöissä typpilannoituksena annettiin $40 \mathrm{~kg} \mathrm{ha}^{-1}$, muut ravinteet annettiin maan viljavuuden ja herneen tarpeiden perusteella.

Kokeista laskettiin taimitiheydet, mitattiin kasvuston kehitystä eri tavoin kilpailutilanteen selvittämiseksi ja mitattiin siemensadot sekä sadon tärkeimmät laatutekijät. Nämä pää- ja tukikasvin väliseen kilpailuun liittyvät tulokset julkaistaan myöhemmin, ja tässä yhteydessä keskitytään lakoisuuden ilmenemiseen ja tukikasvien merkitykseen laon estäjinä.

\section{MTT:n herneaineisto}

Herneaineistossa on yhteensä 280 koetta MTT:n eri koepaikoilta vuodesta 1970 eteenpäin. Kasvupaikasta on olemassa tiedot maalajista tärkeimpine viljavuustietoineen, mutta ei maan multavuudesta. Kokeiden toteuttamistiedoista otettiin käyttöön lannoitustiedot sekä kylvö- ja tuleentumispäivämäärät. Mitatuista muuttujista tarkasteltiin estimoituja keskiarvoja lakoprosentista, sadosta, kasvuston pituudesta ja kasvuajasta. Estimaatit laskettiin niin, että genotyyppien ja olosuhteiden vaikutukset saatiin eriteltyä ja tässä tutkimuksessa tarkastellaan vain olosuhteisiin liittyviä estimaatteja. Lakoisuus on arvioitu visuaalisesti lajikekoeohjeiden mukaisesti. Niiden mukaan lako on $0 \%$, kun kasvusto on koko ruudun alalta täysin pystyssä ja $100 \%$, kun se on täysin maata myöten laossa. Jos ruudusta puolet on maata myöten ja puolet täysin pystyssä, on lakoisuus $50 \%$. Toisaalta myös tilanteessa, jossa lakoa on koko ruudun alalla, mutta herne on vain puolittain painunut maata kohti, merkitään lakoisuudeksi $50 \%$. Näin ollen laon laadussa voi samalla lakoisuuden arvolla olla sävyeroja, mutta prosenttiarvo kuvaa kuitenkin tyydyttävästi lakoa kussakin tilanteessa.

Sadesummaa ja keskilämpötilaa sekä kuukausittain että kuuden tuleentumista edeltävän viikon aikana tarkasteltiin mitattujen muuttujien yhteydessä. Varianssikomponenttitarkastelun avulla selvitettiin, miten eri tekijöillä voidaan selittää lako-, sato- ja kasvuston pituusaineistoissa esiintyvää vaihtelua. Lako osoittautui muuttujaksi, jonka vaihtelua voitiin muita muuttujia laajemmin selittää erilaisilla olosuhteisiin liittyvillä muuttujilla. Regressio- ja kovarianssianalyysejä käytettiin selvittämään sekä olosuhteiden vaikutuksen suuruutta että merkitsevyyttä. Ensimmäisessä tilastollisessa mallissa olivat mukana kaikki säämuuttujat, maalaji (karkeat kivennäismaat ja savimaat), kasvuaika, pituus ja sato. Muuttujat, jotka olivat selvimmin ei-merkitseviä, poistettiin ennen uutta analyysiä. Analyysiä tarkennettiin toistamalla se uudella mallilla viiteen otteeseen, jossa vaiheessa katsottiin muuttujien keskinäinen korrelaatio eli eliminoitiin multikollineaarisuus. Kahdeksannen mallin jälkeen jäljellä oli seitsemän muuttujaa, jotka parhaiten selittivät lakoa. Näiden selittäjien osalta laskettiin lisäksi logistisella regressiolla riski sille, että herne menee joko 30 tai 60 -prosenttisesti lakoon. 


\section{Tulokset ja tulosten tarkastelu}

\section{Tukikasvikokeet 2009 - 2011}

Herne kasvoi molemmissa tukikasvikokeissa rehevästi vuonna 2009. Puhtaan herneen siemensato oli kokeessa 1 hieman alle $5000 \mathrm{~kg} \mathrm{ha}^{-1}$ ja kokeessa 2 noin $5500 \mathrm{~kg} \mathrm{ha}^{-1}$. Kokeen 1 tukikasveista kaura tuotti siemensatoa noin 600, ohra 500, kääpiökaura 300 ja kevätvehnä vain noin $100 \mathrm{~kg} \mathrm{ha}^{-1}$. Tukikasvit eivät vähentäneet herneen satoa merkitsevästi ja kokonaissato oli kaurojen ja herneen seoksissa suurin. Kokeessa 2 herneen kanssa samana päivänä kylvetty kaura alensi herneen satoa selvästi eniten eli noin $1000 \mathrm{~kg} \mathrm{ha}^{-1}$. Aikaisimmin kylvetyn kauran siemensato oli myös tässä kokeessa noin $600 \mathrm{~kg}$ $h^{-1}$. Kauran sato pieneni jyrkästi kylvön viivästyessä ja viimeisen kylvöajan kaura kasvoi hyvin vaatimattomasti. Kummankaan kokeen yhdessäkään koeruudussa ei esiintynyt lakoa. Näin siis siitäkin huolimatta, että Hulda ei ole nykylajikkeiden laonkestävin, kasvusto oli rehevä, pelto melko multavaa ja palkojen täyttymisen aikaan saatiin viikon välein kaksi noin $10 \mathrm{~mm}$ sadetta.

Kesä 2010 ei ollut herneen kasvun kannalta yhtä otollinen kuin edeltäjänsä. Puhtaan herneen siemensato oli kokeessa 1 hieman alle $2500 \mathrm{~kg} \mathrm{ha}^{-1}$ ja tukiviljojen kanssa hieman alle $2000 \mathrm{~kg} \mathrm{ha}^{-1}$. Kokeen 1 tukikasveista kaura tuotti siemensatoa lähes 600, ohra lähes 500, kääpiökaura noin 700 ja kevätvehnä noin $330 \mathrm{~kg} \mathrm{ha}^{-1}$. Kaksi jälkimmäistä tukikasvia näytti siis jonkin verran hyötyneen heikommasta hernekasvustosta edelliseen kesään verrattuna. Kokeen 2 myöhempiä tukikauran kylvöjä ei päästy tekemään suunnitelman mukaisesti, koska ensimmäisen kylvön jälkeen sää muuttui hyvin sateiseksi. Toinen ja kolmas kauran kylvö myöhästyivät niin paljon, että kaura ei tuottanut siemensatoa lainkaan. Herne kärsi märkyydestä ja kasvu vaihteli koealueen sisälläkin. Suureen vaihteluun nähden koejäsenten välillä ei ollut merkitseviä eroja, koejäsenten keskimääräinen siemensato oli välillä 1790 $1960 \mathrm{~kg} \mathrm{ha}^{-1}$. Kahden vähemmän märkyydestä kärsineen kerranteen perusteella tosin puhtaan herneen siemensato oli $300 \mathrm{~kg} \mathrm{ha}^{-1}$ suurempi kuin herneen, jonka seuraksi oli samana päivänä kylvetty kauraa.

Kokeessa 1 ei myöskään kesällä 2010 ollut lainkaan lakoa. Kokeessa 2 lakoa oli lähinnä kentän etureunan kahdessa kerranteessa, jotka erityisesti kärsivät alkukesän runsaista sateista. Herne jäi harvaksi ja heikkokasvuiseksi, jolloin vierekkäisten kasviyksilöiden kärhetkään eivät ylettyneet toisiaan tukemaan, vaan kasvit painuivat maata vasten. Siellä missä herne oli kasvanut paremmin, ei lakoakaan ollut. Siten myös vuoden 2010 osalta voidaan todeta, että normaalikasvuinen herne ei mennyt lakoon, eikä tukikasvi vaikuttanut asiaan.

Vuonna 2011 lakoutuminen pyrittiin varmistamaan sijoittamalla koe alueelle, joka viljelykokemusten mukaan kasvoi yleensä rehevästi eikä kärsinyt helposti kuivuudesta. Multavuudeltaan tämä hiuesaveksi määritelty maa tosin oli vastaavanlaista kuin ensimmäisen kesän koealue eli luokassa "multava", humuspitoisuuden ollessa hieman yli $5 \%$. Sadetukseenkin oli varauduttu, mutta sateet kesän mittaan auttoivat herneen rehevään kasvuun.

Kesällä 2011 herne kasvoi erittäin hyvin. Multava maa sieti hyvin alkukesän lievän kuivuuden ja sen jälkeen sateita saatiin sopivasti. Herne kasvoi tavallista pidemmäksi ja palkoja kehittyi runsaasti. Runsaat sateet palkojen täyttymisen aikaan varmistivat sen, että herne alkoi mennä lakoon. Siemensadot ovat tätä kirjoitettaessa vielä laskematta.

Lakoutuminen alkoi tukikasvittomasta ja kääpiökauraa tukikasvina kasvaneesta koejäsenestä 26.7., herneen kehitysasteella 80 eli juuri kun palot olivat turvonneet täyteen kokoonsa. Tukikasvittoman herneen ja ruutujen, joissa tukikasvina oli kevätvehnä, lakoisuus kasvoi nopeasti tämän jälkeen (kuva 1). Tämä oli loogista, sillä edellisinä kesinäkin herneen seassa heikosti menestynyt kevätvehnä kasvoi kesällä 2011 hyvin vaatimattomasti. Kaura tukikasvina esti herneen lakoutumista varsin hyvin. Tavallista korkeammaksi kasvanut herne vei tehon kääpiökauralta; se esti herneen lakoa vain, kun herne ei ollut aivan pisimmillään. Ohra piti hernettä pystyssä pidempään kuin kääpiökaura, vaikka lopulta lako oli samaa luokkaa. 


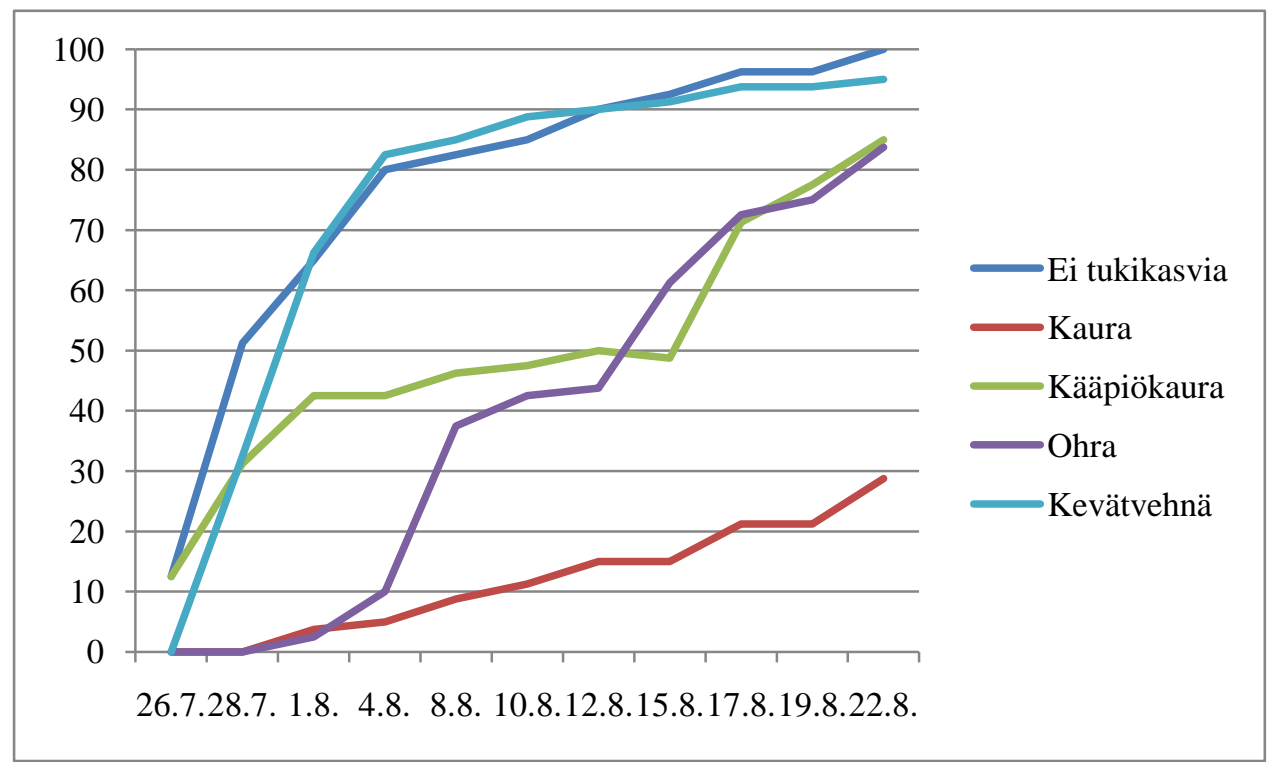

Kuva 1: Herneen lakoisuuden (\% koko kasvustosta) kehittyminen ilman tukikasvia ja eri tukikasvien kanssa neljän viikon kuluessa lakoutumisen alkamisesta.

Myös laon voimakkuudessa oli koejäsenten välillä eroja. Lakoon menneen kasvuston osalta annettiin arvo yhdestä kolmeen laon voimakkuudesta. Arvot olivat pienimmät, kun kaura oli tukikasvina (kuva 2). Myös ohra ja kääpiökaura auttoivat hieman hernettä pysymään irti maan pinnasta, mutta kevätvehnän kanssa lakoherne oli lopulta kokonaan maata myöten kuten puhdaskin herne.

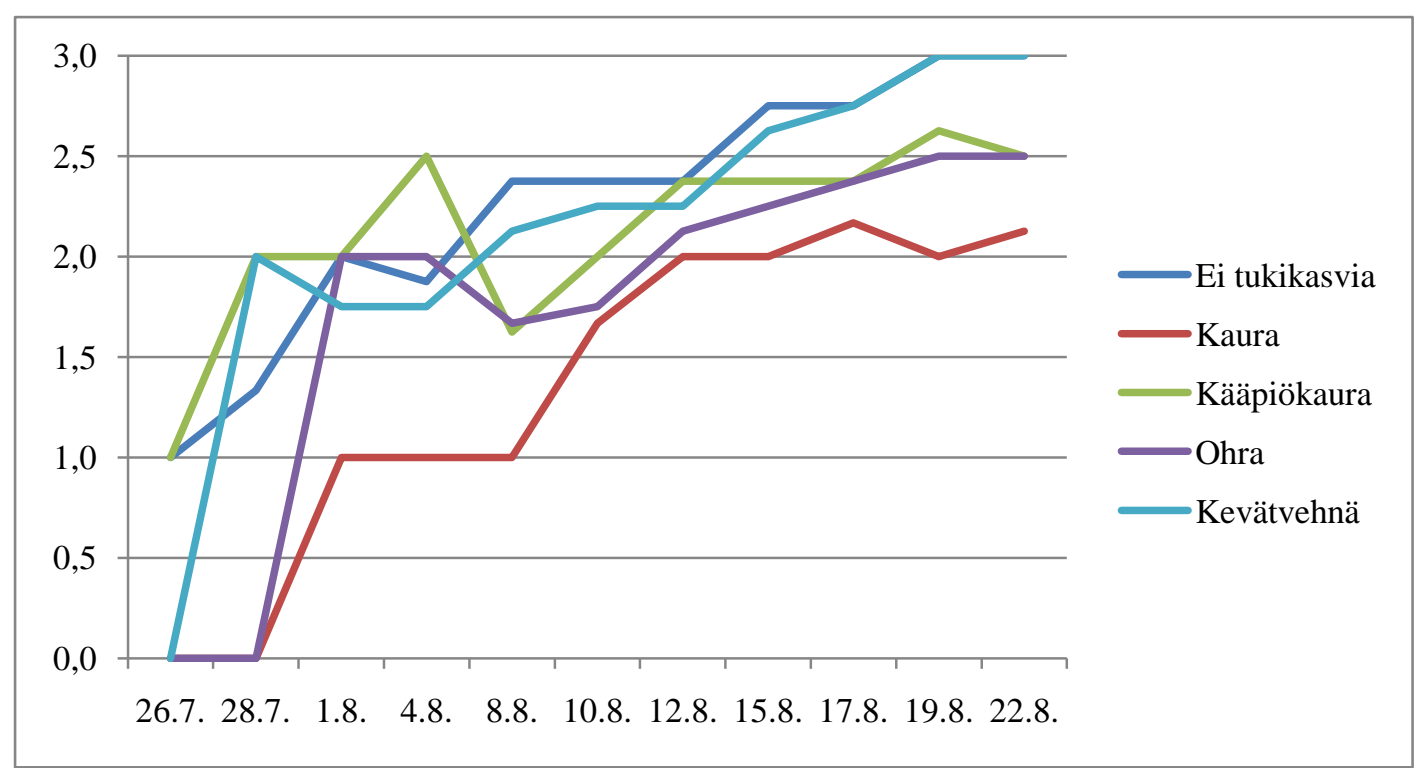

Kuva 2: Herneen laon voimakkuus neljän viikon aikana ennen täystuleentumista ilman tukikasvia ja sen kanssa niissä koeruudun osissa, joissa herne ei ollut täysin pystyssä. Aivan maata myöten $=3$, painunut melko lähelle maata $=2$ ja painunut jonkin verran $=1$.

Tulokset vahvistavat aiempaa käsitystä kauran soveltuvuudesta herneen tukikasviksi (Kontturi ym. 2005). Aikaisemmassa Kovaherne -hankkeessa saatiin myös kääpiökaurasta lupaavia tuloksia. Tässä esiteltyjen tukikasvikokeiden perusteella kääpiökaura soveltuu useimmiten hyvin seokseen herneen kanssa, mutta hyvin rehevään ja varsien pituutta lisäävään herneen kasvuun johtavissa oloissa kääpiökauran kyky pitää hernettä pystyssä näyttää tavallista kauraa heikommalta. Kääpiökauraa ei siten kannata käyttää tukikasvina myöskään sellaisten hernelajikkeiden kanssa, joiden varren pituus on kokeissa käytettyä Huldaa pidempi. 


\section{Pitkäaikainen herneaineisto}

MTT:n herneaineistossa lako oli karkeissa kivennäismaissa keskimäärin $20 \%$ suurempi kuin savimaissa. Kun hernesato kasvoi $1000 \mathrm{~kg} \mathrm{ha}^{-1}$, lako lisääntyi 4,6 \%. Kymmenen millin sadesumma $4-6$ viikkoa ennen tuleentumista lisäsi lakoa 1,5\%. Lähes sama vaikutus oli toukokuussa tai kesäkuussa saadulla $10 \mathrm{~mm}$ sateella. Keskilämpötilan nousu yhdellä asteella kolmen viimeisen viikon aikana ennen tuleentumista vähensi lakoa $0,45 \%$. Aineiston mukaan pituuden kasvu $10 \mathrm{~cm}$ :llä vähensi lakoa $1,9 \%$.

Karkea kivennäismaa lisäsi savimaahan verrattuna riskin 2,4 -kertaiseksi sille, että herneen lako oli vähintään $30 \%$. Sadon nousu tuhannella kilolla hehtaaria kohti lisäsi riskin keskimäärin kaksinkertaiseksi. Kymmenen millin sadesumma $4-6$ viikkoa ennen tuleentumista lisäsi laon riskiä 1,16 kertaiseksi. Toukokuun sateen kerroin oli 1,08 ja kesäkuun 1,17. Jokaista kertynyttä 10 mm kohti riski kertautuu siten, että esimerkiksi $20 \mathrm{~mm}$ sadesumman aiheuttama riskin kasvu on 1,16 x 1,16 kertainen. Siten esimerkiksi, jos $4-6$ viikkoa ennen tuleentumista satoi $40 \mathrm{~mm}$, oli 1,8 -kertainen riski sille, että herne meni vähintään 30 prosenttisesti lakoon verrattuna siihen ettei olisi satanut ollenkaan.

Karkea kivennäismaa lisäsi savimaahan verrattuna riskin 5,2 -kertaiseksi sille, että herneen lako oli vähintään $60 \%$. Sadon nousu tuhannella kilolla hehtaaria kohti lisäsi riskin keskimäärin puolitoistakertaiseksi. Kymmenen millin sadesumma $4-6$ viikkoa ennen tuleentumista lisäsi lakoriskiä 1,14 kertaiseksi. Toukokuun sateen kerroin oli 1,06 ja kesäkuun 1,07.

Kesällä 2011 Jokioisilla satoi 4 - 6 viikkoa ennen kokeemme Hulda -herneen tuleentumista 100 $\mathrm{mm}$. Teoriassa riski vähintään $60 \%$ lakoutumiselle kasvoi noille viikoille osuvaan sateettomaan jaksoon verrattuna $1,14^{10}$ eli 3,7 -kertaiseksi.

Yhteenvetona kaikista tilastollisista malleista, jotka aineistosta tehtiin, selitti sade $4-6$ viikkoa ennen herneen tuleentumista lakoutumista ylipäänsä. Maalaji selitti erityisesti suurta eli yli $60 \%$ lakoisuutta. Alkukesän sateet sekä siemensadon lisääntyminen selittivät pienten eli yli $30 \%$ lakojen lisääntymistä.

\section{Johtopäätökset}

Pitkäaikaisten herneaineistojen tarkastelu sääaineistojen rinnalla vahvisti oletuksia herneen lakoa aiheuttavista riskitekijöistä. Maan multavuuden merkitystä ei tosin aineistosta saanut irti, mutta huomattava lakoriskin lisääntyminen savia kevyemmissä maissa kuvannee osittain samaa ilmiötä. Kohtuulliset sateet alkukesällä auttavat herneen hyvään kasvuun ja antavat edellytykset runsaaseen palkojen muodostukseen, mikä osaltaan lisää myös lakoutumisen edellytyksiä. Biologisten tekijöiden, kasvifysiologian ja fysiikan lakienkin pohjalta päätelty palkojen täyttymisvaiheen sateisuuden lakoa lisäävä riski sai myös tilastollista vahvistusta. Jatkossa sääaineistoja on hyvä tarkastella myös siitä näkökulmasta, miten suuri laon teoreettinen mahdollisuus on tulevia kasvukausia ajatellen. Kauran, kääpiökauran tai ohran viljely herneen tukikasvina vähentää lakoa ja viivästyttää laon etenemistä. Kesän 2011 tukikasvikoe osoitti, että erittäin lakoalttiissa oloissa kaura on viljoistamme paras herneen lakoutumisen estäjä. Kauran kylvön viivyttäminen ei näytä olevan perusteltua, vaan sen voi kylvää heti herneen kylvön jälkeen. Alustavien satotulosten perusteella tukikasvi voi pienentää herneen siemensatoa etenkin vuosina, jolloin herneen kasvu on heikkoa. Kauran ja herneen yhteenlaskettu sato on kuitenkin usein yhtä suuri tai suurempi kuin puhtaan herneen siemensato.

\section{Kirjallisuus}

Kontturi, M., Laine, A., Niskanen, M. ja Peltonen-Sainio, P. 2005. Ripaus kauraa tukee hernekasvuston. Koetoiminta ja Käytäntö -liite 13.6.2005, 62. vuosikerta, numero 2, sivu 3.

Känkänen, H. 2011. Herne, mainettaan varmempi viljelykasvi. Maaseudun Tulevaisuus 4.5.2011, s. 2 (yliö). Känkänen, H., Kontturi, M. 1988. Kylvötiheyden vaikutus lehtityypiltään erilaisten herneiden sadon muodostumiseen. Maatalouden tutkimuskeskus. Tiedote 22/88: 69 p. 